\title{
Mediating Effects of Organizational Commitment on the Relationship between Beauty Industry Managers' Leadership and Customer Orientation
}

Sun-Ju Park

Department of Beauty Health Care, Yongin University, Yongin-si, Gyeonggi-do, Korea

Corresponding author: Sun-Ju Park, Department of Beauty Business, Yongin University, 134 Yongindaehak-ro, Cheoin-gu, Yongin-si, Gyeonggi-do 17092, Korea

Tel.: +82 3180203694

Fax: +82 3180203694

Email: sj7864@hanmail.net

Received January 7, 2018

Revised April 16, 2018

Accepted April 23, 2018

Published June 30, 2018

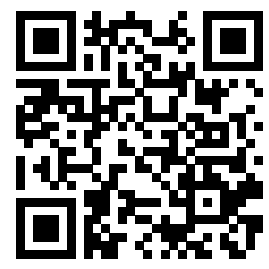

\begin{abstract}
Purpose: The purpose of this study is to examine the effects of managers' leadership types on customer orientation in the beauty industry, focusing on the mediating effects of organizational commitment. Methods: The Statistical Package for the Social Sciences (SPSS) and Analysis of Moment Structures (AMOS) were conducted to identify the effects of leadership types on customer orientation in the beauty industry through organizational commitment. Results: While transformational leadership did not affect customer orientation in general, it did so when organizational commitment was set as a mediator. Transactional leadership had statistically significant effects on customer orientation, and it also affected customer orientation through organizational commitment as a mediating variable. Conclusion: In the beauty industry, charisma, individualized consideration, and intellectual stimulation are factors of transformational leadership that affect customer orientation through organizational commitment. Therefore, efforts should be made to encourage charisma, individualized consideration, and intellectual stimulation to increase employee satisfaction-the most important part of internal marketing. In addition, exceptional management and conditional compensation are factors of transactional leadership that affect organizational commitment and customer orientation. Thus, when continuous efforts are made for superiors' exceptional management and gestures of conditional compensation toward employees, corporate profits will increase through organizational commitment and customer orientation, which will prevent employees from changing jobs.
\end{abstract}

Keywords: Beauty industry, Transformational leadership, Transactional leadership, Organizational commitment, Customer orientation

\section{Introduction}

급속하게 변화하는 시대에 기업문화를 만드는 조직의 규모와 변화가 광범위하면서도 매우 빠르게 이루어져가고 있으며, 이러 한 분위기 속에서 기업의 조직간 구성원들의 관계가 무엇보다 중 요하다고 할 수 있다. 현대에 와서 여성의 사회진출의 비율이 상 승함에 따라 고객들의 수준은 더욱 높아지고 있고, 미용실의 과 다한 경쟁으로 인해서 미용 서비스는 환경적으로 급변하는 시기 에 놓여 있다. 다른 서비스업의 조직과 비교해보면 미용 서비스 업의 가장 큰 특징은 인적 서비스가 다른 기업에 비해 무엇보다 중요한 품질요인이다. 미용 서비스업의 조직 특성은 직원들이 미
용 분야 전문성을 가져야 하며 직원들에 대한 의존성이 높다. 또 한 다양한 스타일을 원하는 고객들에게 만족된 서비스를 제공하 기 위해서는 전문지식과 기술뿐만 아니라 조직 구성원간의 의사 소통이 무엇보다 중요하다. 기업이 경쟁에서 생존하고 성장해 나 가기 위해서는 가장 중요한 자원 중 하나인 인적자원은 기업의 성패를 가르는 요소로서 인적자원의 조직환경에 빠르게 대처하 고 효율성을 높일 수 있는 직원의 능력을 향상시킨다. 그러므로 조직의 성과를 높일 수 있는 리더십의 중요성을 강조할 수 밖에 없다.

Kim \& Youn (2017)의 연구를 보면 가맹본사 교육강사의 변 혁적 리더십이 가맹점 경영성과에 긍정적 영향을 미치고, 프랜차 
이즈 관계품질인 만족과 신뢰의 매개효과로 가맹점의 경영성과 가 더욱 제고되는 것으로 나타났다. Goo \& Lee (2005)의 연구 에서는 변혁적, 거래적 리더십이 구성원의 조직몰입에 유의한 영 향을 미치는 것으로 나타났다. 이 연구결과로서 변혁적 리더십을 통하여 직원이 맡고 있는 직무에 자긍심을 높이고 이러한 자긍심 을 통해 서비스의 질과 조직몰입을 향상시킨다고 보았고, 거래적 리더십은 직원에 따라 차별적으로 활용하여 조직심리를 파악함 으로써 조직몰입을 향상시켜야 한다는 시사점을 제시하였다. 또 한, 전문 직원이 직무에 충실하고 전문 직업성을 인식하게 될 경 우에 직무만족, 능력부여, 몰입에 유의한 영향을 주어 결국 고객 에 대한 서비스 질을 높이게 된다고 하였다. 이처럼 미용산업에 서 서비스 질을 향상시키기 위해서는 소수가 근무하는 환경일지 라도 전문 직업인으로서 경영관리가 될 수 있도록 동기부여를 통 해 조직몰입을 높여야 할 것이다(Oh, 2009). 고객지향성은 기업 의 모든 기능과 수준에 존재하고, 그것은 정책의 변화와 사상을 받아들이도록 종업원에 용기를 일으키는 과정으로서 내부 마케 팅을 통해 달성된다(Dennis \& Bocarnea, 2005). 미용 서비스 산업은 급변하는 시장의 흐름과 무한 경쟁을 하고 있는 근무 환 경 속에서 최대 목표는 직원의 동기 부여를 통한 조직의 몰입으 로 생산성을 높이기 위함이다. 이를 위해 미용산업 경영자의 리 더십은 직원의 고객지향성에 매우 중요한 영향을 미치며 이러한 리더십을 중심으로 직원의 조직몰입은 미용산업 경영에 시사하 는 바가 클 것으로 생각한다.

본 연구는 미용산업 경영자의 리더십이 조직몰입을 통해 고객 지향성에 미치는 영향을 실증 연구 모형을 통해 검증해보고자 한 다. 이에 리더십이 고객지향성에 미치는 영향을 주는 과정에서 의 매개변수로서 조직몰입이 어떤 역할을 하는가에 대해서도 알 아보고자 한다. 이와 더불어 미용 서비스업의 마케팅적 시사점을 제시하고자 한다.

\section{Methods}

\section{1. 연구의 모형}

본 연구에서는 선행연구를 바탕으로 미용산업 경영자의 리더 십 유형이 구성원의 조직몰입 및 고객지향성에 미치는 영향에 대 해 알아보기 위해 본 연구의 모형을 Figure 1 과 같이 제시하였 다.

\section{2. 변수의 조작적 정의}

본 연구에서는 설정한 모형과 가설을 검증하기 위해 다음과 같 은 요인으로 측정하였다.

1) 독립변수: 변혁적 리더십, 거래적 리더십

미용산업의 변혁적 리더십을 측정하기 위해 관련 선행연구

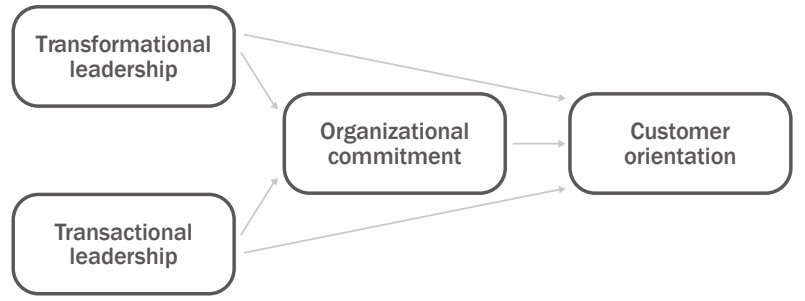

Figure 1. Research model.

This model shown was to indicate effects of managers' leadership types on customer orientation in the beauty industry. Organizational commitment was used as a parameter.

Bass (1990), Kim (2009)의 연구를 토대로 미용산업의 서비스 에 맞게 수정 보완하여 변혁적 리더십 10 개 문항, 거래적 리더십 6 개 문항으로 구성하였다. 먼저, 변혁적 리더십의 구성요소로는 ' 카리스마' 4 개 문항, '개별적 고려' 3 개 문항, '지적 자극' 3 개의 문 항으로 구성하였다. 거래적 리더십은 '조건적 보상' 3 개 문항, '예 외적 관리' 3 개 문항으로 구성하였으며, 모든 문항에 대해 5 점 척 도로 측정하였다.

\section{2) 종속변수: 고객지향성}

고객지향성이란 고객의 이해, 고객의 욕구에 가장 부합되는 방 향으로 고객을 만족시키려는 대 고객 접근 자세이다(Hoffman \& Ingram, 1991). 고객지향성은 Narver \& Slater (1990)의 선행 연구를 바탕으로, "고객이 만족스러운 의사결정을 할 수 있도록 도와주려는 욕구, 고객의 욕구를 충족시킬 수 있는 노력, 고객과 의 약속을 충실히 이행, 고객의 요구를 이해하고 해결하려는 노 력, 내가 제공하는 서비스가 고객에게 어떻게 평가될지에 대해 항상 생각"의 5 가지 문항에 대해 5 점 척도로 측정하였다.

3) 매개변수: 조직몰입

조직몰입은 조직 구성원이 조직에 대해 갖는 조직의 목표, 규 범에 대한 일치감, 심리적 애착 감으로 정의한다. 본 연구에서는 Allen \& Meyer (1990)가 개발한 척도 중 일부를 수정하여 총 5 개 문항에 대해 5 점 척도로 측정변수를 구성하였다(Bandalos et al., 2003).

\section{3. 가설 설정}

본 연구는 실증분석을 위해 이론적 배경 및 선행연구를 바탕 으로 미용산업 경영자의 리더십 유형이 구성원의 조직몰입 및 고 객지향성에 미치는 영향에 대해 알아보기 위해 연구모형을 구축 하였으며, 이를 근거로 실증연구에서 검증해야 할 가설을 다음과 같이 설정하였다. 
1) 미용산업 경영자의 리더십 유형이 조직몰입에 미치는 영향 관계

Buchanan II (1974)의 연구를 보면, 리더십의 관계가 조직의 가치와 목표, 본인의 역할, 정서적 애착심으로 나타나는 조직몰 입에 유의적인 영향을 미치는 것으로 나타났다. 변혁적 리더십은 리더와 더불어 직원들에게 공동의 임무와 비전을 제시하고 목표 에 대한 직원들의 몰입 수준을 높인다고 보았으며, 변혁적 특성 이 높은 리더의 경우 변혁적 특성이 낮은 리더에 비해 직원들의 조직 몰입 수준을 향상시킨다고 하였다(Meyer \& Allen, 1984). 이와 같은 선행연구를 바탕으로 리더십 유형이 조직몰입에 유의 적인 영향을 미칠 것이라고 추론할 수 있으므로 다음과 같은 가 설을 설정할 수 있다.

$\mathrm{H} 1$ : 리더십 유형이 조직몰입에 유의적인 영향을 미칠 것이다.

H1-1: 변혁적 리더십은 조직몰입에 유의적인 영향을 미칠 것 이다.

H1-2: 거래적 리더십은 조직몰입에 유의적인 영향을 미칠 것 이다.

2) 미용산업 경영자의 리더십 유형이 고객지향성에 미치는 영향 관 계

기업이 고객과 장기적인 관계 형성을 갖고 유지시키는데 있어 서 접점직원의 고객지향적인 부분이 매우 중요하며 접점직원의 고객지향성은 고객과의 관계에 있어 매우 긍정적인 영향을 미치 는 것으로 나타났으며, 변혁적 리더의 경우 접점직원의 고객지 향성이 증가하는 것으로 나타났다(Yi, 2010). Podsakoff et al. (1990)은 변혁적 리더들의 특성으로 직원들은 리더와 조직, 직 원들이 수행해야 하는 직무에 높은 조직 몰입도를 유지하므로 직 원들의 만족도가 높게 나타나고, 이러한 결과로 조직의 성과에 긍정적 영향을 끼친다고 보았다. 이는 직무의 만족과 높은 조직 의 몰입은 고객지향성에 영향을 미친다는 것을 알 수 있다. 이와 같은 선행연구를 바탕으로 리더십 유형이 고객지향성에 유의적 인 영향을 미칠 것이라고 추론할 수 있으므로 다음과 같은 가설 을 설정할 수 있다.

$\mathrm{H} 2$ : 리더십 유형이 고객지향성에 유의적인 영향을 미칠 것이 다.

$\mathrm{H} 2-1$ : 변혁적 리더십은 고객지향성에 유의적인 영향을 미칠 것이다.

H2-2: 거래적 리더십은 고객지향성에 유의적인 영향을 미칠 것이다.

\section{3) 미용산업의 조직몰입이 고객지향성에 미치는 영향 관계}

Lee (2011)은 기업의 내부 마케팅이 조직몰입 및 고객지향성 에 대한 연구에서는 조직몰입이 고객지향성에 유의한 영향을 미 치는 것으로 조사되었다. 호텔직원들의 조직몰입, 고객지향성에 대한 연구에서는 조직몰입이 고객지향성에 긍정적인 영향을 미
치는 것으로 나타났다(Park et al., 2012). 이와 같은 선행연구 를 바탕으로 조직몰입이 고객지향성에 유의적인 영향을 미칠 것 이라고 추론할 수 있으므로 다음과 같은 가설을 설정할 수 있다.

$\mathrm{H} 3$ : 조직몰입이 고객지향성에 유의적인 영향을 미칠 것이다.

4) 미용산업 경영자의 리더십 유형과 고객지향성의 관계에서 조직 몰입의 매개효과

Kelley (1992)의 연구에서는 리더십 유형이 고객지향성의 원 인과 결과 부분에 효과가 있음을 제시하였다. 이와 같은 선행연 구를 바탕으로 조직몰입은 리더십 유형이 고객지향성을 유발하 는 매개 역할을 할 것이라고 추론할 수 있으므로 다음과 같은 가 설을 설정할 수 있다.

$\mathrm{H} 4$ : 조직몰입은 리더십 유형과 고객지향성의 관계를 매개할 것이다.

H4-1: 조직몰입은 변혁적 리더십과 고객지향성의 관계를 매 개할 것이다.

H4-2: 조직몰입은 거래적 리더십과 고객지향성의 관계를 매 개할 것이다.

\section{4. 자료수집 및 분석방법}

1) 조사대상

본 연구는 리더십 유형이 고객지향성에 미치는 영향에 대한 연 구로 서울과 경기지역의 미용산업을 대상으로 조사하였다. 서 울·경기 소재 미용산업에서 근무하는 직원을 대상으로 2017년 8 월 14 일부터 8 월 25 일까지 총 250 부의 설문지를 배포하여 자기 기입 설문지를 작성하도록 의뢰하였으며, 회수된 설문지 중 불성 실한 설문지 11 부를 제외하고 총 239 부를 본 연구의 분석에 사 용하였다.

\section{2) 자료분석 방법}

수집된 자료는 데이터 코딩 과정을 거쳐 조사대상자의 인구통 계학적 특성과 주요 변수의 특성을 분석하기 위해 SPSS (ver. 22; $\mathrm{IBM}, \mathrm{USA}$ ) 프로그램을 이용하여 재 코딩과 오류 검토 작업을 거 친 후, 빈도분석 및 기술분석, 상관관계분석을 통해 다중공선성 문제를 진단하였다. 본 연구는 연구모형에서 제시된 구성개념들 간에 상호 관계를 검증하기 위해 $\mathrm{AMOS}$ (SPSS AMOS 22; IBM) 를 이용하였다. 결측치의 비율이 크지 않아 분석자료의 결측치를 고려한 모수추정방법(full information maximum likelihood, FIML)으로 분석하였다. 구조방정식 모형의 적합도 평가 시 상대 적 적합도 지수인 Turker-Lewis index (TLI)와 comparative fit index $(\mathrm{CFI})$ 를 이용하였고, 절대적 적합도 지수는 root mean square error of approximation (RMSEA)를 이용하였 다. 마지막으로 매개효과의 통계적 유의미성은 Bootstapping을 통해 분석하였다. 
Effects of Leadership on Customer Orientation in the Beauty Industry

Table 1. Demographic characteristics of the subjects

\begin{tabular}{|c|c|c|c|}
\hline Division & & Frequency $(\mathrm{N})$ & Percent (\%) \\
\hline \multirow{2}{*}{ Gender } & Male & 46 & 19.2 \\
\hline & Female & 193 & 80.8 \\
\hline \multirow{5}{*}{ Age } & Under 20 & 5 & 2.1 \\
\hline & $20 \mathrm{~s}$ & 115 & 48.1 \\
\hline & $30 \mathrm{~s}$ & 76 & 31.8 \\
\hline & $40 \mathrm{~s}$ & 35 & 14.6 \\
\hline & Over 50 & 8 & 3.3 \\
\hline \multirow{4}{*}{ Education } & Non-grade school graduate & 10 & 4.2 \\
\hline & Non-high school graduate & 120 & 50.2 \\
\hline & Non-university graduate & 70 & 29.3 \\
\hline & Graduate school education or higher & 39 & 16.3 \\
\hline \multirow{2}{*}{ Marital status } & Single & 162 & 67.8 \\
\hline & Married & 77 & 32.2 \\
\hline \multirow{5}{*}{ Income } & Under KRW 1,000,000 & 6 & 2.5 \\
\hline & KRW 1,000,000-2,000,000 & 67 & 28.0 \\
\hline & KRW 2,000,000-3,000,000 & 128 & 53.6 \\
\hline & KRW 3,000,000-4,000,000 & 26 & 10.9 \\
\hline & Over KRW 4,000,000 & 12 & 5.0 \\
\hline \multirow{5}{*}{ Position } & Unemployed & 46 & 19.2 \\
\hline & Intern & 68 & 28.5 \\
\hline & Designer & 109 & 45.6 \\
\hline & Higher positions & 16 & 6.7 \\
\hline & Total & 239 & 100.0 \\
\hline
\end{tabular}

\section{Table 2. Descriptive statistics of major variables}

\begin{tabular}{|c|c|c|c|c|c|c|}
\hline Variables & Mean & $\begin{array}{l}\text { Standard } \\
\text { deviation }\end{array}$ & Minimum values & $\begin{array}{l}\text { Maximum } \\
\text { values }\end{array}$ & Skewness & Kurtosis \\
\hline $\begin{array}{l}\text { Transformational } \\
\text { leadership }\end{array}$ & 4.18 & 0.52 & 2.80 & 5.00 & -0.226 & -0.570 \\
\hline Charisma & 4.16 & 0.55 & 2.25 & 5.00 & -0.284 & -0.196 \\
\hline $\begin{array}{l}\text { Individualized } \\
\text { consideration }\end{array}$ & 4.11 & 0.65 & 2.00 & 5.00 & -0.338 & -0.232 \\
\hline $\begin{array}{l}\text { Intellectual } \\
\text { stimulation }\end{array}$ & 4.30 & 0.60 & 2.67 & 5.00 & -0.481 & -0.458 \\
\hline $\begin{array}{l}\text { Transactional } \\
\text { leadership }\end{array}$ & 3.77 & 0.49 & 2.17 & 5.00 & 0.220 & 0.457 \\
\hline $\begin{array}{l}\text { Conditional } \\
\text { compensation }\end{array}$ & 3.71 & 0.56 & 2.00 & 5.00 & 0.139 & 0.055 \\
\hline $\begin{array}{l}\text { Exceptional } \\
\text { management }\end{array}$ & 3.84 & 0.59 & 2.33 & 5.00 & 0.029 & -0.136 \\
\hline $\begin{array}{l}\text { Organizational } \\
\text { commitment }\end{array}$ & 4.07 & 0.54 & 2.60 & 5.00 & -0.301 & -0.009 \\
\hline $\begin{array}{l}\text { Customer } \\
\text { orientation }\end{array}$ & 3.82 & 0.50 & 2.40 & 5.00 & 0.106 & -0.226 \\
\hline
\end{tabular}




\section{Results and Discussion}

\section{1. 표본의 인구 통계적 특성}

연구대상자의 인구 통계학적 특성은 Table 1 과 같다. 성별의 경우 남성이 46명(19.2\%), 여성이 193명(80.8\%)으로 여성의 비 율이 매우 높은 것으로 나타났다. 연령은 20 대가 115 명(48.1\%) 으로 가장 높게 나타났으며, 30대가 76명(31.8\%), 40대가 35명 (14.6\%), 50세 이상 8명(3.3\%), 20세 미만 5명(2.1\%)의 순으 로 나타났다. 학력은 전문대 졸업 이하 전체 대상자의 $50.2 \%$ 로 연구대상자의 $1 / 2$ 이상을 차지하였다. 결혼여부는 미혼이 162 명

(67.8\%)으로 기혼 77 명(32.2\%)에 비해 높게 나타났다. 월평균
소득은 200-300만원 미만 128명(53.6\%)으로 가장 높게 조사 되었으며, 100-200만원 미만 67명(28.0\%), 300-400만원 미 만 26명(10.9\%), 400만원 이상 12명(5.0\%), 100만원 미만 6명 (2.5\%)의 분포를 보였다. 직위는 디자이너 109 명(45.6\%)가 연 구대상자 중에서 가장 많았으며, 인턴 68명(28.5\%), 스텝 46명 $(19.2 \%)$, 실장 이상 16 명 $(6.7 \%)$ 의 순으로 나타났다.

\section{2. 주요변수의 기술통계 분석}

주요변수의 기술통계 및 정규성을 실시한 결과는 Table 2에 제시된 바와 같다. 주요변수의 평균을 살펴보면 독립변수인 변혁 적 리더십은 5점 만점에 4.18 (standard deviation, $\mathrm{SD}=0.52$ )

\section{Table 3. Reliability analysis}

\begin{tabular}{lcc}
\hline Factors & Number of questions & Cronbach's $\alpha$ \\
Transformational leadership & 10 & 0.864 \\
Transactional leadership & 6 & 0.719 \\
Organizational commitment & 5 & 0.762 \\
Customer orientation & 5 & 0.679 \\
\hline
\end{tabular}

Table 4. Analysis of measurement models

\begin{tabular}{|c|c|c|c|c|c|c|}
\hline \multirow{2}{*}{ Latent variables } & \multirow{2}{*}{$\begin{array}{l}\text { Measurement } \\
\text { variables }\end{array}$} & \multicolumn{2}{|c|}{ Estimate } & \multirow{2}{*}{ S.E. } & \multirow{2}{*}{ Critical ratio } & \multirow{2}{*}{$p$} \\
\hline & & B & $\beta$ & & & \\
\hline \multirow{3}{*}{$\begin{array}{l}\text { Transformational } \\
\text { leadership }\end{array}$} & Charisma & 1.000 & 0.751 & & & \\
\hline & $\begin{array}{l}\text { Individualized } \\
\text { consideration }\end{array}$ & 1.139 & 0.789 & 0.100 & $11.352^{* * *}$ & 0.000 \\
\hline & Intellectual stimulation & 1.053 & 0.854 & 0.090 & $11.720^{* * *}$ & 0.000 \\
\hline \multirow{2}{*}{$\begin{array}{l}\text { Transactional } \\
\text { leadership }\end{array}$} & $\begin{array}{l}\text { Conditional } \\
\text { compensation }\end{array}$ & 1.000 & 0.714 & & & \\
\hline & $\begin{array}{l}\text { Exceptional } \\
\text { management }\end{array}$ & 0.861 & 0.641 & 0.157 & $5.476^{* * *}$ & 0.000 \\
\hline \multirow{5}{*}{$\begin{array}{l}\text { Organizational } \\
\text { commitment }\end{array}$} & $\begin{array}{l}\text { Organizational } \\
\text { commitment } 1\end{array}$ & 1.000 & 0.559 & & & \\
\hline & $\begin{array}{l}\text { Organizational } \\
\text { commitment } 2\end{array}$ & 0.872 & 0.501 & 0.147 & $5.945^{* * *}$ & 0.000 \\
\hline & $\begin{array}{l}\text { Organizational } \\
\text { commitment } 3\end{array}$ & 1.296 & 0.664 & 0.181 & $7.155^{* * *}$ & 0.000 \\
\hline & $\begin{array}{l}\text { Organizational } \\
\text { commitment } 4\end{array}$ & 1.286 & 0.724 & 0.172 & $7.481^{* * *}$ & 0.000 \\
\hline & $\begin{array}{l}\text { Organizational } \\
\text { commitment } 5\end{array}$ & 1.337 & 0.679 & 0.185 & $7.245^{* * *}$ & 0.000 \\
\hline \multirow{5}{*}{ Customer orientation } & Customer orientation 1 & 1.000 & 0.538 & & & \\
\hline & Customer orientation 2 & 1.390 & 0.623 & 0.229 & $6.078^{* * *}$ & 0.000 \\
\hline & Customer orientation 3 & 1.039 & 0.518 & 0.189 & $5.495^{* * *}$ & 0.000 \\
\hline & Customer orientation 4 & 1.125 & 0.465 & 0.223 & $5.043^{* * *}$ & 0.000 \\
\hline & Customer orientation 5 & 1.127 & 0.535 & 0.203 & $5.552^{* * *}$ & 0.000 \\
\hline
\end{tabular}

${ }^{*} p<0.05 ;{ }^{* *} p<0.01 ;{ }^{* * *} p<0.001 ; \mathrm{B}$, unstandardized coefficients; $\beta$, standardized coefficients; S.E., standard error. 
Effects of Leadership on Customer Orientation in the Beauty Industry

Table 5. Correlations between variables

\begin{tabular}{|c|c|c|c|c|}
\hline & $\begin{array}{c}\text { Transformational } \\
\text { leadership }\end{array}$ & $\begin{array}{l}\text { Transactional } \\
\text { leadership }\end{array}$ & $\begin{array}{c}\text { Organizational } \\
\text { commitment }\end{array}$ & $\begin{array}{l}\text { Customer } \\
\text { orientation }\end{array}$ \\
\hline Transformational leadership & 1 & & & \\
\hline Transactional leadership & $0.267^{* * *}$ & 1 & & \\
\hline Organizational commitment & $0.357^{* * *}$ & $0.289^{* * *}$ & 1 & \\
\hline Customer orientation & $0.254^{* * *}$ & $0.391^{* * *}$ & $0.484^{* * *}$ & 1 \\
\hline
\end{tabular}

Table 6. Goodness of fit of measurement models

\begin{tabular}{lcccccc}
\hline & $x^{2}$ & $\mathrm{df}$ & $p$ & TLI & CFI & RMSEA \\
$\begin{array}{l}\text { Measurement } \\
\text { models }\end{array}$ & 154.184 & 83 & 0.000 & 0.907 & 0.926 & 0.060 \\
\hline
\end{tabular}

$\mathrm{X}^{2}$, chi-squared test; df, degrees of freedom; TLI, turker lewis index; CFI, comparative fit index; RMSEA, root mean square error of approximation.

Table 7. Analysis results of structural models

\begin{tabular}{|c|c|c|c|c|c|}
\hline \multirow{2}{*}{ Route } & \multicolumn{2}{|c|}{ Estimate } & \multirow{2}{*}{ S.E. } & \multirow{2}{*}{ Critical ratio } & \multirow{2}{*}{$p$} \\
\hline & B & $\beta$ & & & \\
\hline $\begin{array}{l}\text { Transformational leadership } \rightarrow \\
\text { Organizational commitment }\end{array}$ & 0.327 & 0.358 & 0.085 & $3.860^{* * *}$ & 0.000 \\
\hline $\begin{array}{l}\text { Transactional leadership } \rightarrow \\
\text { Organizational commitment }\end{array}$ & 0.278 & 0.285 & 0.102 & $2.719^{* *}$ & 0.007 \\
\hline $\begin{array}{l}\text { Transformational leadership } \rightarrow \\
\text { Customer orientation }\end{array}$ & -0.027 & -0.033 & 0.074 & -0.360 & 0.719 \\
\hline $\begin{array}{l}\text { Transactional leadership } \rightarrow \\
\text { Customer orientation }\end{array}$ & 0.357 & 0.420 & 0.108 & $3.298^{* * *}$ & 0.000 \\
\hline $\begin{array}{l}\text { Organizational commitment } \rightarrow \\
\text { Customer orientation }\end{array}$ & 0.412 & 0.472 & 0.108 & $3.814^{* * *}$ & 0.000 \\
\hline \multicolumn{6}{|c|}{$\begin{array}{l}\mathrm{X}^{2}=154.184 ; \mathrm{df}=83 ; p=0.000 ; \mathrm{TLI}=0.907 ; \mathrm{CFI}=0.926 ; \mathrm{RMSEA}=0.060 ;{ }^{* *} p<0.01 ;{ }^{* * *} p<0.001 ; \mathrm{B}, \text { unstandardized coefficients; } \beta, \text { standardized } \\
\text { coefficients; S.E., standard error; } x^{2} \text {, chi-squared test; } \mathrm{df} \text {, degrees of freedom; TLI, Tucker Lewis index; CFI, comparative fit index; RMSEA, roo } \\
\text { mean square error of approximation. }\end{array}$} \\
\hline Routes between variables & Estimates of me & ects & Standard deviation & \multicolumn{2}{|c|}{$95 \%$ confidence interval } \\
\hline $\begin{array}{l}\text { Transformational leadership } \rightarrow \\
\text { Organizational commitment } \rightarrow \\
\text { Customer orientation }\end{array}$ & \multicolumn{2}{|c|}{0.169} & 0.067 & \multicolumn{2}{|c|}{$0.065-0.319$} \\
\hline $\begin{array}{l}\text { Transactional leadership } \rightarrow \\
\text { Organizational commitment } \rightarrow \\
\text { Customer orientation }\end{array}$ & \multicolumn{2}{|c|}{0.135} & 0.057 & \multicolumn{2}{|c|}{$0.047-0.247$} \\
\hline
\end{tabular}


로 나타났다. 거래적 리더십은 5점 만점에 $3.77(\mathrm{SD}=0.49)$ 로 나타나 직원들이 상사의 거래적 리더십 보다 변혁적 리더십을 높 게 느끼는 것으로 나타났다. 매개변수인 조직몰입은 5 점 만점에 $4.07(\mathrm{SD}=0.54)$ 로 나타났고, 종속변수인 고객지향성은 5점 만 점에 $3.82(\mathrm{SD}=0.50)$ 로 나타났다.

구조방정식 모형에서는 각각의 변수들의 분포 정상 조건이 충 족되지 못할 경우 왜곡된 결과를 도출할 수 있다. 본 연구에서 사 용한 주요 변수의 편포도와 첨도는 절대값 2 미만의 값을 보여 구 조방정식 모형을 적용하는데 필요한 정상분포의 조건을 충족시 키고 있다(Hong et al., 2003).

\section{3. 측정도구의 신뢰도와 측정모형의 분석}

1) 신뢰도 분석

신뢰도(reliability)란 동일한 개념에 대해 측정을 반복했을 때 동일한 측정값을 얻을 가능성을 말하는 것으로 측정된 결과치의 안정성, 일관성, 예측가능성, 정확성 등과 관련된 개념이다. 본 연구에서는 신뢰도 개념 중에서 널리 인정하고 있는 Cronbach's $\alpha$ 값을 구하는 방법을 시행하였다. 일반적인 사회과학 연구에서 탐색적인 연구단계에서는 Cronbach's $\alpha$ 값이 0.60 이상이면 신 뢰도가 높다고 보고 있다(Chaiy, 2001).

본 연구에서는 다항목(multi-items)으로 측정하였다. 변혁 적리더십 10 개의 문항에 대한 신뢰도 분석결과 Cronbach's $\alpha$ 값이 0.864 , 거래적리더십 6 개 문항에 대한 신뢰도 분석결과 Cronbach's $\alpha$ 값이 0.719 , 조직몰입 5 개 문항에 대한 신뢰도 분 석결과 Cronbach's $\alpha$ 값이 0.762 , 고객지향성 5 개 문항에 대한 신뢰도 분석결과 Cronbach's $\alpha$ 값이 0.679로 나타나 척도들의 신뢰도는 모두 유의하다고 할 수 있다(Table 3).

\section{2) 측정모형의 분석결과}

Figure 1은 미용산업에서 관리자의 리더십 효과에 대한 고객 지향성의 모델로서 조직몰입이 매개변수로 사용되었다. 측정모 형의 분석은 Figure 1에서 측정 변수들에 대한 확인적 요인분석 을 통해 이루어지는데, 그 결과는 Table 4 와 같다. 변혁적 리더 십, 거래적 리더십, 조직몰입, 고객지향성을 나타내는 각각의 측 정변수들이 모두 유의수준 0.001 에서 유의미한 것으로 나타나 측정변수들이 잠재변수를 잘 반영하고 있으며 타당하게 구성하 고 있음을 알 수 있다.

\section{4. 변수간 상관 분석}

본 연구에서 사용된 각 변수간의 다중공선성 문제를 살펴보고 자 Table 5 와 같이 상관관계를 알아보았다. 이를 분석한 결과 통 계적으로 유의한 상관계수는 0.254 에서 0.484 로 나타났으며, 모든 상관계수는 0.484 이하로 확인되어 다중공선성이 의심되는 변수는 없는 것으로 나타났다.

\section{5. 가설 검증과 해설}

1) 모형의 적합성 검증

전체적인 모형의 적합도를 평가하기 위한 $\chi^{2}$ 통계량, degrees of freedom (df), $p$-value, TLI, CFI, RMSEA의 기준을 이 용한 결과, 전체 모형의 경우 $\chi^{2}=154.184, \mathrm{df}=83, p=0.000$, $\mathrm{TLI}=0.907, \mathrm{CFI}=0.926$, RMSEA=0.060 (TLI-CFI 0.9 이상 이면 적합, RMSEA 0.08 이하이면 적합)의 지수로 나타나 모형 에 있어서 적합하다고 할 수 있다(Table 6).

\section{2) 가설 검증}

리더십 유형과 조직몰입, 고객지향성 변수를 통제한 후 분 석하였다. 결과에 대한 모형적합도는 $\chi^{2}=154.184, \mathrm{df}=83$, $p=0.000, \mathrm{TLI}=0.907, \mathrm{CFI}=0.926, \mathrm{RMSEA}=0.060$ 로 나타나, 필요한 적합도를 충족시켰으며 경로계수는 Table 7과 같다. 모형 의 분석 결과를 구체적으로 살펴보면 다음과 같다. 변혁적 리더 십에서 조직몰입에 이르는 경로는 critical ratio $(\mathrm{CR})=3.860^{\star \star \star}$, 거래적 리더십에서 조직몰입에 이르는 경로는 $\mathrm{CR}=2.719^{\star \star}$, 변 혁적 리더십에서 고객지향성에 이르는 경로는 $\mathrm{CR}=-0.360$, 거 래적 리더십에서 고객지향성에 이르는 경로는 $\mathrm{CR}=3.298^{\star \star \star}$, 조 직몰입이 고객지향성에 이르는 경로는 $\mathrm{CR}=3.814^{\star \star \star}$ 로 나타났다. 먼저 변혁적 리더십은 조직몰입 $(\beta=0.358)$ 에 대해 $p<0.001$ 의 수준에서 통계적으로 유의미하였고, 거래적 리더십은 조직몰입 $(\beta=0.285)$ 에 대해 $p<0.01$ 수준에서 통계적으로 유의미한 영향 을 미치는 것으로 조사되었다. 또한 변혁적 리더십이 고객지향성 $(\beta=-0.033)$ 에 유의미한 영향을 미치지 않은 것으로 나타났다. 반면에 거래적 리더십은 고객지향성 $(\beta=0.420)$ 에 대해 $p<0.001$ 수준에서 통계적으로 유의미하게 나타났다. 조직몰입은 고객지 향성 $(\beta=0.472)$ 에 대해 $p<0.001$ 수준에서 통계적으로 유의미하 게 나타났다. 이러한 결과는 상사의 변혁적 리더십(카리스마, 개 별적 고려, 지적 자극)과 거래적 리더십(예외적 관리, 조건적 보 상)이 있을수록 직원은 조직에 몰입하게 됨을 의미한다. 또한 상 사의 거래적 리더십이 높을수록 직원의 고객지향성에 긍정적인 영향을 미친다는 것을 알 수 있다. 마지막으로 직원들의 조직몰 입이 높을수록 직원들의 고객지향성이 높아지는 것을 의미한다.

\section{3) 매개효과 검증}

조직몰입의 매개변수에 대한 매개효과 검증을 실시한 결과는 다음과 같다. 매개효과를 살펴보기 위해 편향 수정 부트스트래 핑(bootstrapping) 검증을 실시하였으며, 매개효과 추정치, 표 준오차, 부트스트랩(bootstrap) 95\% 신뢰구간 값을 분석하였다. 그 결과는 Table 8에서 보는 바와 같이, 변혁적 리더십과 고객지 향성 관계에서 조직몰입의 매개효과는 $95 \%$ 신뢰구간에서 각각 0.065-0.319로 나타났고, 거래적 리더십과 고객지향성 관계에 서 조직몰입의 매개효과는 0.047-0.247로 분석되어, 0을 포함 
하지 않은 것으로 나타났다. 즉 조직몰입의 매개효과는 $p<0.05$ 수준에서 모두 통계적으로 유의한 것으로 검증되었다.

\section{Conclusion}

본 연구는 미용산업 경영자의 리더십이 고객지향성에 미치는 영향력을 검증하고, 이 관계에서 조직몰입을 매개하여 작용하는 경로를 파악하는 것이다. 이를 위해 미용산업에서 직원들을 대상 으로 설문지를 배포하여 239 부를 본 연구의 분석에 사용하였다. 본 연구를 위해 SPSS 프로그램과 AMOS 프로그램을 적용하여 통계적인 검증을 실시하였으며 연구결과를 바탕으로 미용 서비 스산업의 마케팅적 시사점을 제시하고자 한다.

본 연구의 결과를 요약하면 다음과 같다.

첫째, 변혁적 리더십이 조직몰입에 미치는 영향 $(\beta=0.358$, $p$-value $=0.000)$ 은 $p\langle 0.001$ 의 수준에서 통계적으로 유의한 긍 정적인 영향을 미치는 것으로 나타났으며, 이는 미용산업에서 변 혁적 리더십의 카리스마, 개별적 고려, 지적 자극요인이 직원들 의 조직몰입에 영향을 미친다는 것을 의미한다. 또한, 거래적 리 더십이 조직몰입에 미치는 영향 $(\beta=0.285, p$-value $=0.007)$ 은 $p<0.01$ 의 수준에서 통계적으로 유의한 긍정적인 영향을 미치는 것으로 나타났으며, 이는 미용산업에서 거래적 리더십의 예외적 관리, 조건적 보상요인이 직원들의 조직몰입에 영향을 미친다는 것을 의미한다.

둘째, 변혁적 리더십이 고객지향성에 미치는 영향 $(\beta=-0.033$, $p$-value $=0.719$ )은 통계적으로 유의하지 않은 것으로 나타났으 며, 이는 미용산업에서 변혁적 리더십의 카리스마, 개별적 고려, 지적 자극이 직원들의 고객지향성에는 영향을 미치지 않는다는 것을 의미한다. 또한, 거래적 리더십이 고객지향성에 미치는 영 향 $(\beta=0.420, p$-value $=0.000)$ 은 $p<0.001$ 의 수준에서 통계적으 로 유의한 긍정적인 영향을 미치는 것으로 나타났으며, 이는 미 용산업에서 거래적 리더십의 예외적 관리, 조건적 보상요인이 직 원들의 고객지향성에 영향을 미친다는 것을 의미한다.

셋째, 조직몰입이 고객지향성에 미치는 영향 $(\beta=0.472$, $p$-value $=0.000)$ 은 $p\langle 0.001$ 의 수준에서 통계적으로 유의한 긍 정적인 영향을 미치는 것으로 나타났으며, 이는 미용산업에서 직 원들의 조직몰입은 고객지향성에 영향을 미친다는 것을 의미한 다.

넷째, 변혁적 리더십이 고객지향성에 미치는 효과는 조직몰입 에 의해 완전 매개( $95 \%$ 신뢰구간 $=0.065-0.319)$ 되는 것으로 나 타났다. 또한, 거래적 리더십이 고객지향성에 미치는 효과는 조 직몰입에 의해 부분 매개( $95 \%$ 신뢰구간=0.047-0.247)되는 것 으로 나타났다. 이는 거래적 리더십의 경우는 조직몰입을 거치지 않고 종속변인인 고객지향성에 영향을 미치지만 변혁적 리더십
은 매개변인인 조직몰입을 통해 고객지향성에 영향을 미친다는 것을 알 수 있다.

본 연구결과가 가지는 마케팅적 시사점은 리더십 유형이 조직 몰입을 통해 고객지향성에 영향을 미치므로 이에 대한 노력이 필 요할 것이다. 미용산업에서 변혁적 리더십인 카리스마, 개별적 고려, 지적자극의 요인은 조직몰입을 통해 고객지향성에 영향을 주는 요인임으로 내부 마케팅의 가장 중요한 부분인 직원의 만족 도를 높이기 위해 상사의 카리스마, 개별적 고려, 지적자극에 대 한 노력이 필요할 것이다. 직원들의 고객지향성이 높아지는 것은 경쟁력을 강화할 수 있는 방안으로 이에 대한 지속적인 관리가 필요할 것이다. 또한 거래적 리더십인 예외적 관리, 조건적 보상 의 요인은 조직몰입과 고객지향성에 영향을 미치므로 직원에 대 한 상사의 예외적 관리와 조건적인 보상이 이루어질 수 있도록 지속적으로 노력을 기울임으로써 직원의 이직을 막을 수 있는 조 직몰입 및 고객지향성을 통해 기업의 이익을 증대시킬 것이다.

본 연구의 한계점으로는 고객지향성에 영향을 주는 매개 변수 를 보다 광범위하게 포함시키지 못하고 선택된 변수만으로 탐색 적 연구로 한정하여 이것이 미용산업의 리더십 유형이 고객지향 성에 미치는 영향을 조직몰입을 매개로 하여 결정요인을 대표한 다고 하는 데에는 한계점을 가지고 있다. 따라서 향후 리더십 유 형이 고객지향성에 영향을 미치는 요인에 대해 다양한 변수를 이 용하여 분석할 필요성이 있다.

\section{Acknowledgements}

이 논문은 2017년도 용인대학교 학술연구조성비 재원으로 수 행된 연구임.

\section{References}

Allen NJ, Meyer JP. The measurement and antecedents of affective, continuance and normative commitment to the organization. Journal of Occupational and Organizational Psychology, 63: 1-18, 1990.

Bandalos DL, Finney SJ, Geske JA. A model of statistics performance based on achievement goal theory. Journal of Educational Psychology, 95: 604-616, 2003.

Bass BM. From transactional to transformational leadership: learning to share the vision. Organizational Dynamics, 18: 19-31, 1990.

Buchanan II B. Building organizational commitment: the socialization of managers in work organizations. Administrative Science Quarterly, 19: 533-546, 1974.

Chaiy S. Social science research methodology. Hakhyunsa, 
Paju, pp235-269, 2001.

Dennis RS, Bocarnea M. Development of the servant leadership assessment instrument. Leadership and Organization Development Journal, 26: 600-615, 2005.

Goo JD, Lee BS. The impact of transformational leadership and transactional leadership on self-esteem and organizational commitment of hotel employees. Journal of Tourism and Leisure Research, 17: 45-60, 2005.

Hoffman KD, Ingram TN. Creating customer-oriented employees: the case in home health care. Journal of Health Care Marketing, 11: 24-32, 1991.

Hong S, Malik ML, Lee MK. Testing configural, metric scalar, and latent mean invariance across genders in sociotropy and autonomy using non-western sample. Educational and Psychological Measurement, 63: 636-654, 2003.

Kelley SW. Developing customer orientation among service employees. Journal of the Academy of Marketing Science, 20: 27-36, 1992.

Kim CN. Factor structure of the multifactor leadership model for the Korean MLQ form 5-45. The Korean Journal of Industrial and Organizational Psychology, 22: 567-596, 2009.

Kim JH, Youn CS. Mediating effects of relationship quality on franchisor leadership and franchisee performance. Asian Journal of Beauty and Cosmetology, 15: 467-477, 2017.

Lee BY. A study on the influence of internal marketing of travel agency to organizational commitment, organizational citizenship behavior, and customer orientation. Academy of Customer Satisfaction Management, 13: 19-38, 2011.

Meyer JP, Allen NJ. Testing the "side-bet theory" of organizational commitment: some methodological consideration. Journal of Applied Psychology, 69: 372378, 1984.

Narver JC, Slater SF. The effect of a market orientation on business profitability. Journal of Marketing, 54: 20-35, 1990.

Oh KH. The effect of beauty salon staffs' organizational conflict on organizational commitment and turnover intention. Asian Journal of Beauty and Cosmetology, 7: 367-383, 2009.

Park BG, Woo SK, Lee YW. Effects of empowerment perceived by residence hotel on organizational commitment and customer orientation. Journal of Hotel \& Resort, 11: 295-310, 2012.

Podsakoff PM, Mackenzie SB, Moorman RH, Fetter R. Transformational leader behaviors and their effects on follower's trust in leader, satisfaction, and organizational citizenship behaviors. The Leadership Quarterly, 1: 107142, 1990.

Yi KY. Effects of leadership style \& personal characteristics on salesforces' customer-orientation. Korea Journal of Business Administration, 23: 3213-3230, 2010. 


\section{국문초록}

\section{미용산업 경영자의 리더십과 고객지향성 관계에 대한 조직몰입의 매개효과}

박선주

용인대학교 미용경영학과, 경기도 용인시, 한국

목적: 본 연구는 미용산업의 리더십 유형이 고객지향성에 미치는 영향을 조직몰입의 매개효과를 중심으로 알아보고자 진행되었 다. 방법: 미용산업에서 리더십 유형이 조직몰입을 통해 어떠한 영향을 미치는지를 규명하기 위해 statistical package for the social sciences (SPSS) 프로그램 분석 및 analysis moment structure (AMOS) 프로그램 분석을 실시하였다. 결과: 변혁적 리더십은 고객 지향성에 영향을 미치지 않는 것으로 나타났으나, 변혁적 리더십이 조직몰입을 매개로 하였을 때는 고객지향성에 영향을 미치는 것 으로 나타났다. 거래적 리더십은 고객지향성에 유의적인 영향을 미치는 것으로 나타났고, 매개변인인 조직몰입을 통해서도 영향을 미치는 것으로 조사되었다. 결론: 미용산업에서 변혁적 리더십인 카리스마, 개별적 고려, 지적 자극의 요인은 조직몰입을 통해 고 객지향성에 영향을 주는 요인으로 내부 마케팅의 가장 중요한 부분인 직원의 만족도를 높이기 위해 상사의 카리스마, 개별적 고려, 지적 자극에 대한 노력이 필요할 것이다. 또한 거래적 리더십인 예외적 관리, 조건적 보상의 요인은 조직몰입과 고객지향성에 영향 을 미치므로 직원에 대한 상사의 예외적 관리와 조건적인 보상이 이루어질 수 있도록 지속적으로 노력을 기울임으로써 직원의 이직 을 막을 수 있는 조직몰입 및 고객지향성을 통해 기업의 이익을 증대시킬 것이다.

핵심어: 미용산업, 변혁적 리더십, 거래적 리더십, 조직몰입, 고객지향성

이 논문은 2017년도 용인대학교 학술연구조성비 재원으로 수행된 연구임.

\section{참고문헌}

김정남. 한국어 MLQ Form 5-45의 요인구조 모형 비교. 한국심리학회지: 산업 및 조직, 22: 567-596, 2009.

김준호, 윤천성. 프랜차이즈 본사 리더십과 가맹점 경영성과에서 프랜차이즈 관계품질의 매개효과. 아시안뷰티화장품학술

지, 15: 467-477, 2017.

구성대, 이방식. 변혁적 리더십과 거래적 리더십이 호텔 종사자의 자긍심과 조직몰입에 미치는 영향. 관광레저연구, $17:$

45-60, 2005.

박병길, 우성근, 이영우. 레지던스 호텔 직원들이 지각하는 임파워먼트가 조직몰입, 고객지향성에 미치는 영향. 호텔리조

트연구, 11: 295-310, 2012.

이감용. 리더십 스타일과 개인적 특성이 판매원의 고객지향성에 미치는 영향. 대한경영학회지, 23: 3213-3230, 2010.

이병열. 여행사의 내부마케팅이 조직몰입과 조직시민행동 및 고객지향성에 미치는 영향. 고객만족경영연구, 13: 19-38,

2011.

오경헌. 미용실 종사자의 조직갈등이 조직몰입과 이직의도에 미치는 영향. 아시안뷰티화장품학술지, 7: 367-383, 2009. 채서일. 사회과학 조사방법론. 학현사, 파주, pp235-269, 2001. 


\section{中文摘要}

\section{组织承诺对美容产业经理人领导力与顾客导向关系的媒介作用}

朴善柱

龙仁大学美容经营学科, 京畿道龙仁市, 韩国

目的：通过关注组织承诺的中介效应来考察美容行业领导类型对顾客导向的影响。方法：通过组织承诺阐明美 容产业的领导类型对顾客导向的影响, 利用statistical package for the social sciences (SPSS) 统计软件和 analysis moment structure (AMOS) 软件进行分析。结果: 尽管变革型领导并没有影响客户导向, 但是当组织 承诺被设定为媒介时, 变革型领导对客户导向具有统计显著的影响。交易型领导对客户导向具有统计显着的影 响, 并且通过组织承诺作为中介变量影响客户导向。结论：在美容行业中, 魅力, 个性化考虑和智力刺激是转 型领导力的因素，通过组织承诺影响顾客导向。因此，应鼓励个人魅力，个性化考虑和智力激励来提高员工满 意度-这是内部营销的最重要部分。另外, 卓越的管理和有条件的薪酬是影响组织承诺和顾客导向的交易领导 力的因素。因此, 当上司对员工的特殊管理和有条件报酬的姿态不断努力时, 企业利润将通过组织承诺和顾客 导向而增加，这将阻止员工转换工作。

关键词：美容产业，变革型领导，交易型领导，组织承诺，顾客导向 
